\title{
Is there a need for a new, an ecological, understanding of legal animal rights?
}

\author{
Brian Favre* \\ University of Lausanne and École normale supérieure
}

Legal animal rights may, in the short term, offer an efficient means to improve the living conditions of animals and how they are treated by human societies. This article argues that this shift to adopt an animal rights framing of the human-animal interaction might also risk producing certain counterproductive effects. It suggests that there is a need for a broader reassessment of the relationships between the human and animal worlds. This article posits that the adoption of legal animal rights as a workable legal solution for the better protection of animals has been increasingly accepted because rights frameworks rely upon a core premise of Western jurisprudence, namely legal subjectivism and the epistemological and axiological assumptions it conveys. The article argues that such an individualistic and dualist approach to legal animal rights will ultimately reveal itself to be insufficient and unable to capture animals as members of concrete social and environmental entanglements. Rather, a true legal revolution is required, which would evoke an ecological understanding of law itself.

Keywords: legal animal rights, legal subject, legal person, relational theory, Western jurisprudence, ecology, zoopolis, legal revolution

\section{INTRODUCTION}

The debates over moral and legal animal rights, although they may still seem esoteric to regular jurists, reveal an unavoidable mutation in the relationship between human and animal in the Western world. Sociologically, this evolution can now be considered a part of the 'civilizing process' of the West: ${ }^{1}$ the gradual transformations of behaviours and emotions alongside an increased sensibility of certain segments of the population regarding the treatment of animals. ${ }^{2}$ Resulting, in particular, from the fact that the economic use of animals has never been so obviously intensive,

* The author expresses his gratitude to the editors (Julia Dehm and Anna Grear) and guest editors (Visa Kurki, Tom Sparks and Saskia Stucki) for their insightful and constructive criticisms on this article. I also thank participants of the (Legal) Animal Rights Workshop at the IVR World Congress held in Luzern for their stimulating presentations and encouraging comments on a previous version of this article.

1. For a presentation of Norbert Elias' civilizing process, see Andrew Linklater and Stephen Mennel, 'Norbert Elias, The Civilizing Process: Sociogenetic and Psychogenetic Investigations an Overview and Assessment' (2010) 49 History and Theory 384, 394ff.

2. See for example some recent surveys. One in collaboration with the French association L214 (Ifop for the Group Animal Politique, La sensibilité des Français à la cause animale à la veille de la séquence électorale (Ifop 2019)) and another one with the American organization Nonhuman Rights Project (NhRP) (Garrett M Broad, Investigating Public Support for the Legal Rights of Nonhuman Animals (Qualtrics 2017)). 
many previously small-scale behaviours towards animals have simply become unbearable. ${ }^{3}$ Accordingly, it is increasingly the case that many jurisdictions have adopted or have tightened animal welfare regulations. But as has been often noted, there is a risk that 'animal welfare regulation simply permits human beings to feel better about exploiting animals'. ${ }^{4}$ Moreover, although the growing number of welfare regulations demonstrates an awareness of the problem, it has not drastically modified the practices. ${ }^{5}$

Legal animal rights are intended precisely to produce an ethical shift in humans' treatment of animals by legal means. In the broad sense in which the term will be used in the following discussion, 'legal animal rights' encompass any attempt to recognize individual animals as the direct beneficiaries of some legal prerogatives afforded by a given juridical system: these may include (but are not limited to) fundamental rights to life, and to bodily integrity. ${ }^{6}$ Given that definition, endowing animals with adequate legal rights ${ }^{7}$ should bring societal attitudes and everyday practice into closer coherence, and ultimately ameliorate humans' attitude towards nonhuman living beings. ${ }^{8}$ Legal rights are often seen as the only tool adequate to this task: in common parlance, only legal rights could offer a direct - and thus ethically adequate protection of the animals themselves, while welfare legislation chiefly emphasizes the duty of humans not to inflict unnecessary suffering. ${ }^{9}$ Instead of mere legal safeguards, graciously allowed by anthropocentric laws, a direct and ethical approach would

3. For example, the practice of chick sexing and male chick culling were unknown in the US before the 1930s, because egg and meat production were not yet separated. The practice then became common in the egg industry: see John H Lunn, 'Chick Sexing' (1948) 36 American Scientist 280, 280-81. Recently, disapproval of this practice has increased in many Western countries: see for example Corinna Reithmayer and Olivier Musshoff, 'Consumer Preferences for Alternatives to Chick Culling in Germany' (2019) 98 Poultry Science 4539, 4539-40.

4. Gary L Francione, Animals as Persons: Essays on the Abolition of Animal Exploitation (Columbia UP 2008) xi.

5. In the European context, see the special report of the European Court of Auditors, Animal Welfare in the EU: Closing the Gap Between Ambitious Goals and Practical Implementation (2018) paras 41-2.

6. Note that the term 'right' in my paper encompasses the four meanings analytically distinguished by WN Hohfeld (see WN Hohfeld, 'Some Fundamental Legal Conceptions as Applied in Judicial Reasoning' (1913-1914) 23 Yale Law Journal 16, 30ff).

7. This paper does not aim to present in detail the different legal animal rights theories, since the question with which it is concerned focuses on the common conceptual background they share. Some scholars see the 'adequacy' of an animal right in broader terms than others. In the deontological perspective of Tom Regan, it would be adequate for animals to acquire legal rights according to their inherent values of 'subject-of-a-life' (Tom Regan, The Case for Animal Rights (2nd edn, University of California Press 2004) 243ff). According to Gary Francione, rights for sentient animals can only be adequate when the latter are freed from any property status (Gary L Francione, Animals, Property, and the Law (Temple UP 1995) 4). For Joel Feinberg, the adequacy of a right should be indexed to animals' interests (Joel Feinberg, 'The Rights of Animals and Future Generations' in William T Blackstone (ed), Philosophy and Environmental Crisis (The University of Georgia Press 1974) 43, 49-51).

8. In what follows, I use the terms 'animals' and 'nonhuman living beings/entities' synonymously. Nevertheless, it should be recognized that the latter terms constitute a form of symbolic violence, as they build on a purely negative definition.

9. For a more comprehensive discussion, see Gary L Francione and Robert Garner, The Animal Rights Debate: Abolition or Regulation? (Columbia UP 2010) 121; and Robert Garner, 'Animal Welfare: A Political Defense' (2006) 1 Journal of Animal Law and Ethics 161, $162 \mathrm{ff}$. 
imbue animals with legal weapons, and thus achieve a balance of power between human and nonhuman living beings within the legal arena.

In this article, I will argue that welcoming animals into such an adversarial understanding of law by granting rights might not be the most suitable answer if the longterm purpose is to achieve less conflictual, more inclusive legal systems that can better encompass the plurality of relationships among living beings. To be clear: what follows is not intended to question the efficiency or the legitimacy of legal animal rights in the short term. It may well be that, in the near future, animal rights can produce changes in the quality of life of certain animals living within or in close contact with human society in ways that are both meaningful and valuable. But I will argue that such an outcome, though positive, would be insufficient. More than forty years ago, Richard Routley asked in a seminal article if it was time for 'a new, an environmental, ethic'. ${ }^{10}$ According to Routley, given the largely anthropocentric nature of Western ethics, only a profound ethical shift could release nonhuman entities from the 'moral void' wherein they were forcibly trapped. In the legal field, legal animal rights represent such an ethical shift, but one that remains within the classical paradigm of abstract rights holders. It is a first step. Yet the interdependence of relationships between human and nonhuman remains beyond its scope. What if, in order to turn our back on that habitual, moral anthropocentrism, we need a further step consisting of an ecological understanding of animal rights? In this paper, my goal is to put animal rights into perspective, and to show that they may be, at a certain point, unfit for that broader ethical-legal task: to construct an understanding of law that is capable of reassessing human-animal relationships in view of their social and environmental interconnectedness, in order to shape new ways of living together.

In section 2 of this article, I will provide an overview of certain relevant features of Western legal culture in order to contextualize the challenge of developing an ecological understanding of animal rights. Drawing on those conclusions, section 3 will assess the extent to which legal animal rights are revolutionary or not. I will argue that legal animal rights are, in fact, far short of revolutionary, given that legal animal rights are based on two intertwined premises of the dominant legal paradigm: legal subjecthood and the opposition between person and thing. Facing the need to legally 'retie the Gordian knot', section 4 will outline why the development of an ecological understanding of animal rights is a project with a much greater potential to overcome our moral anthropocentrism, and in so doing to institute new kinds of human-animal relations.

\section{SOME RELEVANT FEATURES OF WESTERN LEGAL CULTURE}

\subsection{The legal subjectivism of Western jurisprudence}

In antiquity and for much of the Middle Ages, philosophers did not understand the human 'subject' in a psychological and individualistic way. ${ }^{11}$ However, the advent of the Modern era brought with it a tendency to give primacy to the agent as a thinking being who is able to grasp the surrounding world as a vast object of theoretical

10. Richard Routley, 'Is There a Need for a New, an Environmental, Ethic' (XVth World Congress of Philosophy 1973) 205ff.

11. 'Subject' in Barbara Cassin and others, Dictionary of Untranslatables: A Philosophical Lexicon (Princeton UP 2014) 1070-73. 
inquiry. ${ }^{12}$ On the politico-legal level, the emergence of this new understanding of the 'subject' as an empowered individual was contemporaneous with the final dissolution of the feudal system's networked structures of intertwined powers and decentralized sources of law and the emergence of the sovereign nation-state as the centralizing source of positive law. ${ }^{13}$ During this period individual rights (iura) were being disconnected from an encompassing Law $(l e x)^{14}$ and began to be understood as 'a moral quality of a person, enabling him to have or to do something justly'. ${ }^{15}$ As a result, the understanding of law as an heteronomic and pre-existing order gave way in Western jurisprudence to a conception of rightness that was understood solely through the lens of 'subjective' rights. ${ }^{16}$ As John Finnis stated, the modern vocabulary of rights became 'a many-faceted instrument for reporting and asserting the requirements or other implications of a relationship of justice from the point of view of the person(s) who benefit( $s$ ) from that relationship'. ${ }^{17}$ According to this disentanglement trend, the heuristic device of the social contract ${ }^{18}$ - based on the premise of rational, autonomous and independent individuals evolving without any heteronomy - became the key concept used to apprehend the nature of modern society. ${ }^{19}$ Practically, the common prosperity relied thus on the pursuit of private interests which were given primacy in the making of liberal polity. ${ }^{20}$ Since modern societies were understood

12. As Francis Bacon says in New Atlantis: 'The end of our foundation is the knowledge of causes, and secret motions of things; and the enlarging of the bounds of human empire, to the effecting of all things possible' (Basile Montagu (ed), The Works of Francis Bacon, Lord Chancellor of England. Volume I (Carey and Hart 1842) 266).

13. Kaarlo Tuori, Critical Legal Positivism (Applied Legal Philosophy, Ashgate 2002) 10.

14. See Thomas Hobbes, Leviathan (Barnes \& Noble 2004) ch 14, 94.

15. Hugo Grotius, cited in Brian Tierney, The Idea of Natural Rights: Studies on Natural Rights, Natural Law, and Church Law, 1150-1625 (Emory University Studies in Law and Religion, Scholars Press 1997) 325; Yves Charles Zarka, 'The Invention of the Subject of the Law' (1999) 7 British Journal for the History of Philosophy 245, 248. See also Tuori (n 13) $10 \mathrm{ff}$. 16. Helmut Coing, 'Zur Gechichte des Begriffs "subjektives Recht"” in Dieter Simon (ed), Gesammelte Aufsätze zu Rechtsgeschichte, Rechtsphilosophie und Zivilrecht: 1947-1975 (V Klostermann 1982) 251ff; for an explanation of the redundancy of the locution (due to the translation in English of Michel Villey's work), see Thomas Mautner, 'How Rights Became "Subjective"' (2013) 26 Ratio Juris 111, 124ff.

17. John Finnis, Natural Law \& Natural Rights (2nd edn, OUP 2011) 205 (italics in original). 18. Two strains of social contract are distinguished today (see Will Kymlicka, 'The Social Contract Tradition' in Peter Singer (ed), A Companion to Ethics (Blackwell Companions to Philosophy, Blackwell Reference 1991) 188ff. However, the distinction between contrarianism in a Hobbesian sense, and contractualism in a Kantian sense is of little importance for our argument, since they both rely on individual contractors defined by a set of ontological properties (roughly: rationality, autonomy and agency).

19. See Tuori (n 13) 188-9: 'We can call the view of modern society and its members, which such categories as 'subjective right' and 'legal subjectivity' convey, the constitutive social theory of modern society [...]. The members of society are conceived as autonomous individuals, who have freed themselves of the ties of traditional communities and whose mutual relationships are essentially based on their own decisions and choices' (italics in original).

20. As Bernard de Mandeville provocatively stated, 'private vices, by the dexterous management of a skilful politician, may be turned into public benefits' (Bernard de Mandeville, The Fable of the Bees or Private Vices, Publick Benefits (OUP 1924) 369). One century later, Herbert Spencer gave the proper sphere of this 'dexterous management': the defence of men's natural rights (Herbert Spencer, 'The Proper Sphere of Government' in John Offer (ed), Spencer Political Writings (CUP 1993) Letter 1). 
as 'the various aspects of individual well-being in community', ${ }^{21}$ public benefit legally consists primarily of a zero-sum game between conflicting legal prerogatives pursued by independent subjects of rights in the legal market. ${ }^{22}$ The politically emancipatory effect of legal subjectivism in the eighteenth century ${ }^{23}$ did not render the traditional liberal legal subject immune from criticism, however. Beginning in the nineteenth century, ${ }^{24}$ the individual subject of rights has been critiqued as an abstract concept that serves the purposes of bourgeois society ${ }^{25}$ and carries a risk of de-politicization, ${ }^{26}$ and for its failures to protect certain categories of people within the population. ${ }^{27}$ Scholars have also highlighted that this conception of the legal subject cannot properly describe the social reality of corporate actors. ${ }^{28}$ Although it is not possible to discuss here the merits of these various arguments against the traditional liberal conception of the individual legal subject, this discussion shows that when rights holders are considered free and independent to choose their commitments ${ }^{29}$ and expect the judicial system to secure their protected self-interests, ${ }^{30}$ this legal technique fosters an individualistic 'legal conscience'. ${ }^{31}$ Individual legal subjects, considered to be the cause of the existence of legal relationships, ${ }^{32}$ are at the core of Western jurisprudence. ${ }^{33}$

\subsection{Two facets of legal subjectivism: subjecthood and personhood}

In order to assess whether legal animal rights represent a 'revolution', that is, a reversal of the above-mentioned legal paradigm based on legal subjectivism, I will distinguish

21. See Finnis (n 17) 214.

22. Rudolf B Schlesinger and others, Comparative Law: Cases, Text, Materials (University Casebook Series, 6th edn, Foundation Press 1998) 319-20; Ulrich Bröckling, The Entrepreneurial Self: Fabricating a New Type of Subject (Sage 2016) 90-93.

23. See Catherine Colliot-Thélène, 'Les droits subjectifs à l'épreuve de la solidarité sociale' in Olivier Beaud, Catherine Colliot-Thélène and Jean-François Kervégan (eds), Droits subjectifs et citoyenneté (Classiques Garnier 2019) 339-40.

24. See Anatole France speaking in 1894 of 'the majestic equality of the laws, which forbid rich and poor alike to sleep under the bridges, to beg in the streets, and to steal their bread' (Anatole France, Red Lily (1st edn, Dodd, Mead and Company 1925) 91).

25. See Christoph Menke, 'Democratic Citizenship and Subjective Rights: Marx's Riddle' in Olivier Beaud and others (eds), Droits subjectifs et citoyenneté (Classiques Garnier 2019) 100ff. 26. Alain Supiot, Homo juridicus. Essai sur la fonction anthropologique du droit (Seuil 2005) 27; Axel Honneth, Das Recht der Freiheit: Grundriß einer demokratischen Sittlichkeit (Suhrkamp 2013) 157ff; Christoph Menke, Critique of Rights (Polity 2020) 232-33.

27. For example, Martha Minow, 'Interpreting Rights: An Essay for Robert Cover' (1987) 96 Yale Law Journal 1860, $1867 f f$.

28. Gunther Teubner, 'Enterprise Corporatism: New Industrial Policy and the "Essence" of the Legal Person' (1988) 36 The American Journal of Comparative Law 130, 133-40.

29. According to a will theory of rights (see HLA Hart, Essays on Bentham: Jurisprudence and Political Theory (Clarendon Press 2012) 183).

30. When considered through the lens of an interest theory of rights (see Joseph Raz, 'Legal Rights' (1984) 4 Oxford Journal of Legal Studies 1, 14).

31. Niklas Luhmann, 'Subjektive Rechte: Zum Umbau des Rechtsbewußtseins für die moderne Gesellschaft' in Niklas Luhmann (ed), Gesellschaftsstruktur und Semantik (4th edn Suhrkamp 2016) $45 f f$.

32. Which is precisely what, in a nutshell, bothers the communitarian critique. See Michael J Sandel, Liberalism and the Limits of Justice (2nd edn, CUP 1998) 133).

33. See Tuori (n 13) 192-3. 
between two intertwined notions that are often treated as synonyms in positive law: legal subjecthood and legal personhood. ${ }^{34}$ This conceptual distinction allows for a more precise characterization of two facets of the rights-holding paradigm in the context of legal animal rights: one epistemological, ${ }^{35}$ one axiological. ${ }^{36}$ In the following, I provide the relevant historical and conceptual reasons to make such a distinction, before turning to the assessment of these characteristics in legal animal rights in section 3 .

Legal subjecthood became a core logical category in legal thinking during the nineteenth century, ${ }^{37}$ after a long conceptual development which made it possible to understand the legal subject as an independent holder of rights. ${ }^{38}$ The category of 'subject' initially arose as part of a general attempt to rationalize legal analysis through the epistemological dichotomy between subject and object. Since then, this conceptual framework that divides entities into 'subject' and 'object' of rights has continued to organize legal thinking in terms of functional poles. ${ }^{39}$

In Roman law, legal personhood is to be understood as a socio-legal status (persona meaning 'mask' in Latin) assigned to human beings in varying degrees by the juridical system in order to enable them to perform their legal role as legitimate actors on the legal stage ${ }^{40}$ For a long time, the idea of the human individual qua legal person did not exist: a single person could have different personae depending on the legal relationship involved, ${ }^{41}$ and different categories of human beings (notably but not exclusively slaves) were not granted a complete status as 'person' ${ }^{42}$ After successive legal interpretations based on new philosophical assessments of human nature during the Middle Ages, ${ }^{43}$ the modern equivalence between human individuals and legal persons gradually appeared; eventually, individual actors were identified with their personal role once they became liable for their actions. ${ }^{44}$ Under moral definitions of the

34. See for example Bryant Smith, 'Legal Personality' (1928) 37 The Yale Law Journal 283, 283.

35. By legal epistemology, I broadly mean the way law thinks and the conceptual tools it uses to do so (cf Gunther Teubner, 'How the Law Thinks: Towards a Constructivist Epistemology of Law' (1989) 23 Law \& Society Review 727, 730).

36. For another example of the usefulness of the distinction between subjecthood and personhood, see Tomasz Pietrzykowski, 'The Idea of Non-personal Subjects of Law' in Visa AJ Kurki and Tomasz Pietrzykowski (eds), Legal Personhood: Animals, Artificial Intelligence and the Unborn (Springer 2017) 58ff.

37. Luhmann (n 31) 64-8.

38. For the intellectual path that blends the subject as a non-psychological enduring substance (whose rightful position is the result of an allocation by the law) and the modern subject as a legal agent (who is self-endowed with natural rights), see the works of Yves Charles Zarka, 'The Invention of the Subject of the Law' (1999) 7 British Journal for the History of Philosophy 245; Yves Charles Zarka, L'autre voie de la subjectivité. Six études sur le sujet et le droit naturel au XVIIe siècle (Beauchesne 2000). See also Vincent Descombes, Le complément du sujet. Enquête sur le fait d'agir soi-même (Gallimard 2004) 449-54.

39. Olivier Jouanjan, Une histoire de la pensée juridique en Allemagne (1800-1918) (Presse Universitaires de France 2005) 181-4.

40. William Patrick Duff, Personality in Roman Private Law (AM Kelley 1971) 1-5.

41. Yan Thomas, 'Le sujet de droit, la personne et la nature. Sur la critique contemporaine du sujet de droit' (1998) 100 Le Débat 85, 98-100.

42. Roberto Esposito, Les personnes et les choses (Mimésis 2018) 21.

43. See Bartosz Brożek, "The Troublesome "Person"' in Kurki and Pietrzykowski (n 36) 4ff. 44. See John Locke, An Essay Concerning Human Understanding (27th edn, Tegg and Son 1836) 234. Locke speaks of the person as a 'forensic term' describing the responsible agent whose actions can be said to be his or hers. 
human person as an end-in-itself, ${ }^{45}$ the ancient legal dichotomy between person and thing then became more than the purely functional distinction it had been in Rome: it became axiological, since it categorizes legal entities according to a scale of social values. ${ }^{46}$ According to this legal ontology, legal persons are natural when they are human, and juristic when they are corporate, that is when they aggregate individuals. $^{47}$ The result is a paradigmatic and axiological partition of the legal world between person and thing; between those who count as an end-in-themselves and entities that are subject to property: the summa divisio, as it is known in civil law countries. ${ }^{48}$ That division reached its culmination in the second half of the twentieth century, due to the international importance given to the natural person by human rights declarations. ${ }^{49}$ In a nutshell: on the legal stage, only human persons have a role and other entities remain things, mere props in the background. However, costume changes are sometimes possible depending on legal value judgement.

\section{THE UN-REVOLUTIONARY SCOPE OF LEGAL ANIMAL RIGHTS}

\subsection{The epistemological premise: the individual and independent legal subject}

Beginning with Epicurus, it has been maintained that as animals are not autonomous, rational and independent agents, they lack the capacity to enter into a reciprocal contractual relationship and must therefore be left outside of the moral and legal community. ${ }^{50}$ This recurrent objection, though ethologically over-simplistic, ${ }^{51}$ has proved itself to be quite effective. ${ }^{52}$ By denying animals the status of individuals capable

45. Adolf Trendelenburg and Rudolf Eucken, 'Zur Geschichte des Wortes Person' (1908) 13 Kant-Studien 1, 15-16.

46. Helmut Coing, 'Der Rechtsbegriff der menschlichen Person und die Theorien der Menschenrechte' in Ernst Wolff (ed), Beiträge zur Rechtsforschung (De Gruyter and Paul Siebeck 1950) 201ff; David Fagundes, 'What We Talk About When We Talk About Persons: The Language of a Legal Fiction' (2001) 114 Harvard Law Review 1745 1759-66; for further analysis of the orthodox view of the legal person, see Visa AJ Kurki, A Theory of Legal Personhood (OUP 2019) 35-56.

47. John Chipman Gray, The Nature and Sources of the Law (The Macmillan Company 1948) 49; according to the (still dominant) aggregate theory of corporate person, see Susanna Kim Ripken, Corporate Personhood (8th edn, CUP 2019) 23ff, 32.

48. See JR Trahan, 'The Distinction Between Persons and Things' (2008) 1 Journal of Civil Law Studies 9, 9.

49. Coing (n 46) 205; Hans Joas, Die Sakralität der Person. Eine neue Genealogie der Menschenrechte (3rd edn, Suhrkamp 2011) 108ff.

50. Epicurus, Maxims XXXI-XXXIII. For further developments, see Jean-François Lhermitte, L'animal vertueux: dans la philosophie antique à l'époque impériale (Classiques Garnier 2015) 297ff. The argument is still part of the common legal doxa: see for example, Gray (n 47) 43-4; Joseph Raz, 'On the Nature of Rights' (1984) 93 Mind 194, 204-5. It is also to be found in contemporary contractarian philosophy, as in, for example, Peter Carruthers, The Animals Issue: Moral Theory in Practice (CUP 1992) 96-8.

51. For a far more balanced and general assessment of animal capacities drawing on the recent ethological knowledge, see Marc Bekoff, The Emotional Lives of Animals: A Leading Scientist Explores Animal Joy, Sorrow, and Empathy and Why They Matter (New World Library 2007) 88-92; and further Yves Christen, L'animal est-il une personne? (Flammarion 2009) 49ff.

52. For a presentation of this orthodox view of contractarianism (and, later, a contractarian definition of animal rights) see Mark Rowlands, Animal Rights: Moral Theory and Practice (2nd edn, Palgrave Macmillan 2009) 129ff. 
of entering into a contract, most social contractarian theories refuse to allow them any legal rights, ${ }^{53}$ with the effect that animals are not recognized as rights holders. Indeed, in accordance with the epistemological dichotomy outlined above, that which is not a subject of law having rights and obligations, must automatically be an object of law, subjected to somebody else's rights and dependant on the duties of legal subjects. ${ }^{54}$ Several attempts have been made to move animals from the functional category of object to that of subject. Two main approaches have been contemplated in order to conceive of animals as rights holders.

Firstly, an approach has been pursued in which the idea of an average human subject ${ }^{55}$ becomes the standard from which it is possible to extend the circle of the legal community to some nonhuman living entities. ${ }^{56}$ If an animal presents some humanlike capacities (such as sentience, ${ }^{57}$ sufficient consciousness, ${ }^{58}$ or a certain level of autonomy ${ }^{59}$ ), this approach posits that they must be awarded rights because of this similarity. Alternatively, a second approach has emphasized animals as fully-fledged subjects of law, with no direct reference to the human norm. In that case, nonhuman living entities become their own specific measuring standard by which it is possible to assess legal entitlements on their own terms. ${ }^{60}$ Many different moral and legal theories can be labelled as approaching animals in such an 'off-centred' ${ }^{61}$ or non-anthropocentric manner. ${ }^{62}$ For the purpose of this argument, it is not necessary to present all these

53. With the notable exception of a 'neo-Rawlsian' approach, which, considering animals as beneficiaries and not contractors, is precisely intended 'to provide a sound theoretical foundation for the attribution of rights to non-human animals' (see ibid 175).

54. On indirect duties, see Robert Garner, A Theory of Justice for Animals: Animal Rights in a Nonideal World (OUP 2013) 61ff.

55. Gary Francione observes that behind what he calls the 'similar mind' approach, ultimately lies a human choice (which follows an anthropocentric hierarchy) (Francione, Animals as Persons: Essays on the Abolition of Animal Exploitation (n 4) 125). Feminist and ecofeminist scholars have argued further that this approach has often led to a myopic focus, which structurally marginalizes certain voices (Maneesha Deckha, 'Personhood, Intersectionality and Animal Law' (2014) 15 Figurationen 127, 129; Josephine Donovan and Carol J Adams, Introduction to the Feminist Care Tradition in Animal Ethics: A Reader (Columbia UP 2007) 6).

56. See further Joe Wills' discussion of the 'argument from species overlap' and Iyan Offor's discussion of the 'circle of moral concern' in this issue.

57. Francione (n 4) 130.

58. Regan (n 7) $243 \mathrm{ff}$.

59. The courtroom activism of Steven Wise's Nonhuman Rights Project (NhRP) champions this position. In order to convince common law judges of the merits of their habeas corpus cases, NhRP litigations strategically rely on a human-like autonomy as a sufficient but not necessary condition for basic rights to bodily integrity and bodily liberty (Steven M Wise, 'Rattling the Cage Defended' (2002) 43 Boston College Law Review 623, 649-50; Steven M Wise, 'Animal Rights, One Step at a Time' in Cass R Sunstein and Martha Nussbaum (eds), Animal Rights: Current Debates and New Directions (OUP 2004) 28ff). Note that $\mathrm{NhRP}$ litigations are extensively discussed in this issue by Joe Wills.

60. See John Rodman, 'The Liberation of Nature?' (1977) 20 Inquiry 83, 94.

61. For an example based on an anti-discrimination approach, see Taimie L Bryant, 'Similarity or Difference as a Basis for Justice: Must Animals Be Like Humans to Be Legally Protected from Humans? (2007) 70 Law and Contemporary Problems 209, 248.

62. See below, section 4.1 . 
peculiarities in detail, beyond emphasizing that this approach, in contrast to the first, seeks to avoid human chauvinism. ${ }^{63}$

This brief presentation makes it clear how these two apparently contradictory tendencies both rely on a common logic determined by the paradigm of legal subjectivism. Regardless of whether the legal subject is understood to be human-centred or human-decentred, the very idea of a legal subject - understood as an independent holder of rights - appears as a logical necessity. This conception of the legal subject is necessarily implicated when one files habeas corpus petitions on behalf of individual animal clients, ${ }^{64}$ and it is similarly relied upon in deontological approaches which link legal rights to the inherent worth of a subject-of-a-life ${ }^{65}$ or to the fact that most nonhuman living beings are subjects of sentience. ${ }^{66}$ Moreover, this conception of the legal subject also underpins contemporary utilitarianism, which values the consequences of a subject's preferences,${ }^{67}$ and theories that consider subjective interests as sufficient reasons to ascribe legal rights. ${ }^{68}$

In the legal setting, the moral contradiction between a human-centred or a humandecentred approach comes down to a hermeneutical problem of conceptual definition. In a morally human-centred approach, the key legal question is to whom the current definition of legal subject is applicable by virtue of analogy (as a matter of conceptual extension). In a morally human-decentred approach, the key legal question is how to frame a more comprehensive definition of a legal subject which could be applicable to both human and nonhuman entities (as a matter of conceptual intension). Although these approaches have different moral foundations, these two different arguments for granting legal animal rights - because they are deeply rooted in the epistemology of legal subjectivism - have an underlying similarity in that they both focus on animals as individual legal subjects. That is, in order to emancipate animals from a moral discrimination based on species membership ${ }^{69}$ and in order to institute them as competing rights holders to humans ${ }^{70}$ animals must be extricated from the logical category of legal object and be awarded legal rights predicated upon abstract equal subjecthood - 'A's and 'B's in the legal rights market - wherein differences in the scope of the applicable substantive norms may be instituted only on the basis of the sole qualities of the individuals outside any pre-existing legal relationships. ${ }^{71}$

63. The phrase is taken from Richard Routley: Richard Routley and Val Routley, 'Human Chauvinism and Environmental Ethics' in DS Mannison, MA McRobbie and Richard Routley (eds), Environmental Philosophy (Dept of Philosophy, Research School of Social Sciences, Australian National University 1980).

64. Steven M Wise, 'Legal Personhood and the Nonhuman Rights Project' (2010) 17 Animal Law Review 1-4.

65. Regan (n 7) 243ff.

66. Francione (n 4) 11.

67. Peter Singer, 'Animal Liberation at 30' (2003) 50 The New York Review of Books 26.

68. Feinberg (n 7); Visa AJ Kurki, 'Why Things Can Hold Rights: Reconceptualizing the Legal Person' in Kurki and Pietrzykowski (n 36) 83-6. In a similar sense, see Jean-Pierre Marguénaud, Florence Burgat and Jacques Leroy, Le droit animalier (Presses universitaire de France 2016) $245-53$.

69. Peter Singer, Animal Liberation (Avon Books 1975) 7; Gary L Francione, 'Animals Property or Persons?' in Sunstein and Nussbaum (n 59) 131; Alasdair Cochrane, Sentientist Politics: A Theory of Global Inter-Species Justice (OUP 2018) 5.

70. Thomas (n 41) 96; François Ost, La nature hors la loi. L'écologie à l'épreuve du droit (2nd edn, La Découverte 2003) 232.

71. See for example, James Rachels, Created from Animals: The Moral Implications of Darwinism (OUP 1991) 173-4: '[... H]ow an individual may be treated is to be determined, 


\subsection{The axiological premise: the summa divisio}

The legal category of person delimits the sphere of things that matter in the classical Western legal tradition, therefore it is unsurprising that the relegation of nonhuman living entities to the status of things (ie, objects, mostly physical, the very essence of which status means to be controlled by legal persons ${ }^{72}$ ) has meant their total exclusion from the select club of those who are significant in legal terms. ${ }^{73}$ It is for this reason that animal rights advocates have often focused on legal strategies to promote the de-reification ${ }^{74}$ of animals. ${ }^{75}$ As a result, the civil codes of several civil law countries now clearly state that animals are not 'things' in the common sense of the term, ${ }^{76}$ although the legal category of 'thing' still applies. ${ }^{77}$ For example, article $641 a(1)$ of the Swiss civil code reads 'animals are not things', but article 641a(2) adds that 'where no special provisions exist for animals, they are subject to the provisions governing things' ${ }^{78}$ Through this legal fiction that although animals are not categorized as 'things', they can be treated as if they were, ${ }^{79}$ that which is ontologically false (that an animal is a thing in the same way that chairs or potatoes are) is instituted as being legally true (the meaningful legal category of thing applies to an animal). ${ }^{80}$ De-reified

not by considering his group memberships, but by considering his own particular characteristics. If $\mathrm{A}$ is to be treated differently from B, the justification must be in terms of A's individual characteristics and B's individual characteristics'.

72. As the Austrian Civil Code of 1811 bluntly says, 'everything that differs from the person and serves the use of human beings is a thing in the contemplation of law' (\$ 285).

73. See David Fagundes, 'What We Talk About When We Talk About Persons: The Language of a Legal Fiction' (2001) 114 Harvard Law Review 1745, 1746.

74. In this paper, the term 'de-reification' is used to refer to a process which extracts animals from the legal category of thing (res in Latin).

75. Francione (n 4) 25; contra Garner in Francione and Garner (n 9) 142ff; Wise 'Rattling the Cage Defended' (n 59) 662ff; Lucille Boisseau-Sowinski, La désappropriation de l'animal (Publications de la Faculté de droit et des sciences économiques de l'Université de Limoges, Pulim 2013). For an overview of the position in Switzerland see Saskia Stucki, Grundrechte für Tiere: Eine Kritik des geltenden Tierschutzrechts und rechtstheoretische Grundlegung von Tierrechten im Rahmen einer Neupositionierung des Tieres als Rechtssubjekt (Fundamenta juridica, 1 edn, Nomos 2016) 84ff.

76. Austria (\$ 285a ABGB) since 1988; Germany (art 90a BGB) since 1990; Switzerland (art 641a CC) since 2003; Lichtenstein (art 20a SR) since 2003; the province of Catalonia in Spain (art 511

(1) Código Civil de Cataluña) since 2006; the Netherlands (art 2a Burgerlijk Wetboek, Boek 3) since 2011; the Czech Republic (art 494 OZ) since 2012; France (art 515(14) C.civ) since 2015; Quebec (art 898.1 CCQ) since 2015; Colombia (art 655 CC) since 2016; Portugal (art 201 CC) since 2016. Besides, one can find similar norms in other legal contexts: New Zealand (Sct 4 Animal Welfare Amendment Act $\mathrm{N}^{\circ}$ 2) since 2015 and the city of Mexico (art 13-B Constitución Politica de la Ciudad de México) since 2017.

77. Similar mechanisms are used mutatis mutandis in all statutes quoted above.

78. My translation. Note that the unofficial English text of the Swiss civil code uses the term 'object' instead of 'thing'. However the German, French and Italian official versions all use the term 'thing' (Sache, chose, cosa).

79. Xifaras Mikhaïl, 'Fictions juridiques. Remarques sur quelques procédés fictionnels en usage chez les juristes' (2011) 3 Annuaire de l'Institut Michel Villey 451, 454ff.

80. Some civil jurists seem to have misunderstood the axiological scope of these legislative modifications. See, among others, Ombline de Poret, Le statut de l'animal en droit civil: questions choisies de droits réels et de droit successoral (Schulthess 2006) 331, paras 1106-7, who argues that the lay-concept of 'thing' has been erroneously confused with its meaning in legallanguage in order to please activists and educate people. 
animals - treated like things but not anymore as things ${ }^{81}$ - are now more than pure objects but less than full persons. But these unidentified objects stuck in legal limbos, having a lawful position without a clear doctrinal definition, inevitably pose a daunting problem to the common ontology of Western jurisprudence which is focused on a clear-cut and axiological opposition between person and thing: what are they?

After de-reification, therefore, legal personhood for animals is invoked by advocates as a necessary and symbolic ${ }^{82}$ step towards a sound, effective and ethical protection of animals. ${ }^{83}$ As Gunther Teubner says, legal personification thus appears to be 'one of the most successful strategies' to cope with the uncertainty that surrounds the otherness of nonhuman living entities. ${ }^{84}$ But if legal personification seems to be the best answer to the question of the proper status of animals within law's axiological ontology, this argument also implicitly reaffirms the problematic summa divisio - the dichotomy between person or thing - criticized at the de-reification stage as the very argument that explains the necessity of animals' personification, simply because this dichotomy structurally excludes the possibility of any third option. In other words, the argument that animals should be granted legal personhood is based less on political and axiological reflections about potential new legal arrangements which could foster consideration of animals in the future, than on the acknowledged premise that the dichotomy between persons and things is an anthropo-legal constant, an invariable given of our legal ontology in which only (legal) persons are worthy of attention. As early as 1998, Steven Wise was already predicting (and counting on) the inertia of the Western legal taxonomy. He argued then that 'legal personhood for qualified nonhuman animals' would only be a 'minor revolution' that would ultimately remove barriers to 'the overarching values and principles of traditional Western law'; 85 the dualist legal tradition is not to be amended in any way but to be extended as a legal and moral progress. Besides the fact that this argument plainly reveals the complex links that animal ethics have to a certain philosophy of history, ${ }^{86}$ it also confirms

81. Saskia Stucki, 'Rechtstheoretische Reflexionen zur Begründung eines tierlichen Rechtssubjekts' in Margot Michel, Daniela Kühne and Julia Hänni (eds), Animal Law - Tier und Recht: Developments and Perspectives in the 21st Century - Entwicklungen und Perspektiven im 21 Jahrhundert (Dike 2012) 146.

82. Both political and metaphysical, see Ngaire Naffine, 'Who are Law's Persons? From Cheshire Cats to Responsible Subjects' (2003) The Modern Law Review 346, 349ff; Kurki (n 46) 124.

83. Regan (n 7) 266ff; Francione (n 4) 23. Saskia Stucki reaches a similar conclusion (but advocating for a specific animal personhood) after assessing the provisions protecting animals in the Swiss legal system: Stucki (n 75) 123ff, 143 and 333ff. In France, see for example Caroline Regad, Cédric Riot and Sylvie Schmitt (eds), La personnalité juridique de l'animal. L'animal de compagnie (LexisNexis 2018).

84. See Gunther Teubner, 'Rights of Non-Humans? Electronic Agents and Animals as New Actors in Politics and Law' (2006) Journal of Law and Society 497, 503. Instead of considering nonhuman entities as black boxes, only the causal behaviours of which are worthy of legal attention, personification makes it possible to treat them 'as if' they were actors with whom legally mutually dependent relations were possible. With legal personification, an opaque alter becomes legally recognizable for an ego as a less strange alter ego.

85. Steven M Wise, 'Hardly a Revolution - the Eligibility of Nonhuman Animals for DignityRights in a Liberal Democracy' (1998) 22 Vermont Law Review 793, 914.

86. Peter Singer, The Expanding Circle: Ethics, Evolution, and Moral Progress (Princeton UP 2011) 120. The common argument reads as follows: if morality requires the expansion of the circle of concern, law ought to follow a parallel path and expand the circle of law's persons. For a critique, see Rodman (n 60) 91. 
that, whether one seeks legally to express the moral significance of animals through legal personification or through their de-reification, both these agendas are still carried out within and even in the name of the division between person and thing, that is, on the axiological basis of legal subjectivism.

\subsection{Legal animal rights, a revolution within the paradigm}

The epistemological legal subject and the axiological legal person are concepts that seem largely to be shared across the spectrum of legal animal rights advocates. It is therefore difficult to envisage that granting legal personhood to animals would lead to any legal revolution that would imply 'a normative and a scholarly rupture' from the existing paradigm of legal subjectivism. ${ }^{87}$ On the contrary, the idea of subjective rights held by animals as legal persons only reiterates what Kaarlo Tuori calls 'the deep structure of modern law' ${ }^{88}$ At most, we can speak of a legal revolution within the Western legal tradition. But is it appropriate to consider a 'revolution' that merely confirms the dominant paradigm truly revolutionary ${ }^{89}$ To be fair, many interesting approaches in contemporary legal animal rights theory try to escape the dualism that Western jurisprudence constructs between subject/person or object/thing by proposing a third category or a scale of possible categories. ${ }^{90}$ However, although these forceful legal propositions might be theoretically invigorating, I suggest that what they propose only amounts to intermediate individual statuses within the traditional framework, which continues to think primarily in dualistic, binary terms.

Precisely because they do rely on legal subjectivism, legal animal rights are not a theoretical chimaera, ${ }^{91}$ but pragmatic legal techniques strongly rooted in our deep

87. Anne Peters rather speaks of a 'cultural revolution', and of the field of legal scholarship being 'in need of a revolution'. See Anne Peters, 'Introduction: Animal Law - a Paradigm Change' in Anne Peters, Saskia Stucki and Livia Boscardin (eds), Animal Law: Reform or Revolution? (Schulthess 2015) 15, 24-6.

88. Following Kaarlo Tuori, the deep structure of law is 'the common core of legal cultures' that 'vindicates the view of modern law as a historical type of law' (Tuori (n 13) 184 [italics in original]).

89. Following a Kuhnian analysis, the answer is negative. Legal animal rights are not fundamentally at odds with the current paradigm of legal subjectivism which still underpins most of animal rights scholarship. See Thomas Kuhn, The Structure of Scientific Revolutions (2nd edn, International Encyclopedia of United Science, University of Chicago Press 1970) 86.

90. For example, Kurki (n 46) 128 ff; Saskia Stucki, "Die "tierliche Person" als Tertium datur. Eine Extrapolation aus aktuellen tierschutzrechtlichen Subjektivierungsansätzen und kritische Reflexion aus feministische Perspektive' in Christoph Ammann and others (eds), Würde der Kreatur Ethische un rechtliche beiträge zu einem umstrittenen konzept (Schulthess 2015) 287ff; David Chauvet, 'Quelle personnalité est digne pour les animaux' (2015) 62 Droits 217, 227ff; Pierre-Jérôme Delage, La condition animale: essai juridique sur les justes places de l'Homme et de l'animal (Mare \& Martin 2015). See also Eric Reiter who recommends rethinking the entire taxonomy through obligations (actiones): Eric Reiter, 'Rethinking CivilLaw Taxonomy: Persons, Things, and the Problem of Domat's Monster' (2008) 1 Journal of Civil Law Studies 189, $211 \mathrm{ff}$.

91. Contrary to some critiques. See, for example, Jonathan R Lovvorn, 'Animal Law in Action: The Law, Public Perception, and the Limits of Animal Rights Theory as a Basis for Legal Reform' (2006) 12 Animal Law Review 133, 139, who sees the concentration of lawyers and activists on the personhood debate as an unpragmatic stance which impedes the effort to achieve concrete legal progress. 
juridical culture. They are increasingly considered to be sound and efficient solutions in the short term, driving the attention of scholars, ${ }^{92}$ litigators ${ }^{93}$ and legislators ${ }^{94}$ around the world, because they reproduce the handy patterns of legal subjectivism. But as the next section will show, in a longer perspective that considers the modifications of our anthropological dualist scheme which are needed to face the ecological crisis, it becomes necessary to try to think beyond legal subjectivism.

\section{TOWARDS AN ECOLOGICAL UNDERSTANDING OF LEGAL ANIMAL RIGHTS?}

\subsection{The legal need to retie the Gordian knot: the example of Swiss legal taxonomies}

Although the direct justiciability of legal systematics is (of course) limited, ${ }^{95}$ there is little doubt that legal taxonomies reflect the deeply embedded culture of a given legal system. ${ }^{96}$ The example of Swiss animal rights law discussed below, offers a snapshot of the anthropo-legal background shared among Western countries. Using the example of Switzerland, I will illustrate the fundamentally dualistic thinking imposed by the deep structure of law, despite legal changes that may seem far-reaching.

The coordinated modification of the Swiss private law of $2002,{ }^{97}$ which sought to generally improve the legal status of animals, ${ }^{98}$ added new scattered articles which left the overall structure of the civil code unchanged. ${ }^{99}$ The new key provision, article $641 a(1)$ of the civil code, as described above, provides that 'animals are not things', while article $641 a(2)$ adds that 'where no special provisions exist for animals, they are subject to the provisions governing things'. These articles are situated in the book concerning property law and are part of the general provisions devoted to the "nature of ownership'. The legislative intention was not to create any specific legal category for animals, ${ }^{100}$ thus reflecting the code's organization: the summa divisio between persons (art 11ff) and things (art 641ff) remains unchanged. But Switzerland is

92. For example, Kurki and Pietrzykowski (n 36).

93. See for example the different habeas corpus petitions filed by the NhRP: Kevin R Schneider, 'The Evolution of Legal Personhood for Nonhuman Animals in the United States' (2019) 7 Global Journal of Animal Law, available at <http://ojs.abo.fi/ojs/index.php/gjal/article/view/ 1661> accessed 18 May 2020; or the now famous 'Argentinian case' from the Third Court of Guarantees in Mendoza (P-72.254/15) which held that: '[...] primates are legal persons' that 'possess fundamental rights' (certified translation).

94. See for example the effects of the introduction of the restricted biocentric approach in Swiss law: Gieri Bolliger, Animal Dignity Protection in Swiss Law: Status Quo and Future Perspectives (Schulthess 2016) 72ff.

95. François Ost and Michel van de Kerchove, Entre la lettre et l'esprit: les directives d'interprétation en droit (Bruylant 1989) 56-63; María José Falcón y Tella, A Three-Dimensional Theory of Law (Martinus Nijhoff Publishers 2010) 160-61.

96. Ugo Mattei, 'Three Patterns of Law: Taxonomy and Change in the World's Legal Systems' (1997) 45 The American Journal of Comparative Law 5, 5.

97. Joint modifications of the civil code, the code of obligations, the penal code and the bankruptcy code of 4 October 2002 (RO 2003 463).

98. Feuille fédérale (FF) 2002 3885, 3887.

99. See de Poret (n 80) 102 no 295.

100. ibid 128. 
also often pinpointed ${ }^{101}$ for its Animal Welfare Act (LPA), ${ }^{102}$ which seeks to protect 'the dignity and welfare of the animal' (art 1 LPA), ${ }^{103}$ and which relies on what is prima facie a biocentric Constitution. ${ }^{104}$ However, observers generally agree that the human-animal relationship has not been drastically modified in Switzerland. ${ }^{105}$ For example, an initiative to ban the practice of livestock dehorning for intensive breeding purposes was recently defeated in a referendum. ${ }^{106}$ The scope of application of the Animal Welfare Act is in principle limited to vertebrates, it is however left to the executive power to decide which and to what extent invertebrates can also be protected, given the state of science regarding their perception and suffering capabilities (art 2(1) LPA). So far, the LPA's protection has been extended only to cephalopods and walking decapods (art 1 of the Animal Welfare Ordinance), ${ }^{107}$ leaving insects and most molluscs therefore deprived of legal dignity. Until 1 January $2020,{ }^{108}$ male chicks and male calves could still be gassed or shredded as mere 'production waste'. ${ }^{109}$ Wild animals, particularly wolves, despite their status of protected species

101. Otto Schmid and Rahel Kilchsperger, Overview of Animal Welfare Standards and Initiatives in Selected EU and Third Countries: Final Report (EconWelfare, Research Institute of Organic Agriculture (FiBL) 2010) 10.

102. Animal Welfare Act (Loi fédérale sur la protection des animaux of 16 December 2005 [LPA; RS 455]).

103. According to the LPA, there is a violation of dignity when 'the constraints imposed upon [the animal] cannot be justified by overriding interests' (art 3(a) LPA). If every constraint upon animals might be considered as a moral breach of their dignity, only some of them constitute legal violations after a proportionality test, that is when the animal's dignity has been disregarded despite the lack of overriding interests (cf Gieri Bolliger and others, Schweizer Tierschutzstrafrecht in Theorie und Praxis (2nd edn, Schulthess 2019) 62). The minimal welfare requirements (art 3(b)(1-3) LPA) are met when animals' bodily functions and behavioural needs are not disturbed; when they have the opportunity to behave in accordance with their species within the limits of their biological adaptive capacity; when they are clinically healthy; when they are spared pain, distress, injury and anxiety (my translation). The Animal Welfare Ordinance (Ordonnance sur la protection des animaux of 23 April 2008 [OPan; RS 455.1]) and its appendices then give a handful of details such as whether and what kinds of social contact are required depending on the species.

104. Switzerland constitutionally protects the dignity of all living creatures (art 120(2) of the Swiss Federal Constitution, RS 101). Switzerland is the only Western country that has a biocentric constitution. For a critical assessment see Gerald Hess, 'Le biocentrisme est-il applicable? Remarques philosophiques-juridiques sur l'article 120 alinéa 2 de la Constitution fédérale' in Alain Papaux and Alessandro Brenci (eds), Biosphère et droits fondamentaux (Schulthess 2011) 85ff.

105. Bolliger (n 94) 78; Bolliger and others (n 103) 63.

106. Popular initiative 'For the dignity of livestock' (horned cow initiative) from 25 November 2018, rejected by $54.7 \%$ of the voters and most cantons.

107. Animal Welfare Ordinance (Ordonnance sur la protection des animaux of 23 April 2008 [OPan; RS 455.1]).

108. Since then, it is expressly prohibited to shred chicks according to art 20(g) AWO.

109. Although art 26(1)(b) LPA criminalizes intentionally killing an animal in a cruel or malicious way. As recalled in case law (6B_719/2015 s 5.2), what is decisive in order to apply this provision are the motives behind the killing and not the way in which the animal is killed. In the case of male chicks and male calves in the breeding industry, the killings are not considered wanton, but rationally meet an anthropocentric economic imperative (see Bolliger and others (n 103) 166-7). 
under the Bern Convention, ${ }^{110}$ face the risk of eased hunting regulations. ${ }^{111}$ How can this gap between declarations in statues and current practices be explained? In understanding this gap, it is enlightening to consider the underlying legal organization. As in most civil law countries, the Swiss legal system was initially grounded on the positivist aspiration to achieve a legal systematization that could be treated as relatively autonomous from other bodies of norms due to its internal coherence. ${ }^{112}$ Today the Swiss classified compilation, ${ }^{113}$ which was introduced by law in $1967,{ }^{114}$ collects all the federal legislation in force, ${ }^{115}$ which represents roughly 60000 pages divided into nine categories and sub-categories. ${ }^{116}$ Within this systematization, the Animals Welfare Act bears the number 455 and is classified under category 4 ('Education Science - Culture'), following the Federal Act on the Protection of Nature and Cultural Heritage, ${ }^{117}$ which is numbered 451 . By contrast, the Environmental Protection $\mathrm{Act}^{118}$ bears the number 814.01 and is classified under category 8 ('Health - Employment - Social security') and statutes regarding human rights to life, personal liberty, equality and freedom of opinion and information are classified under category 1 ('Sate People - Authorities'). The abusive human treatments of animals described above are unsurprising, given that animals still fall within the first classification (category 4), which represents simply a pool of natural and symbolic resources that are subject to human enjoyment and deserve therefore relatively high indirect protection. By contrast, the second classification (category 8 ) is irremediably linked to the physiological and social conditions necessary for a human person; without mentioning the political community (category 1) which is only made up of humans. It thus seems that the way in which the Swiss compilation is classified amounts to more than a mere editorial work: its organization tells us about the legal consideration of animals in Switzerland. Despite bold legal changes which seem to lean towards legal 'subjectification', animals are still assigned to a category which confines them to the status of mere resources. Roughly stated, the actual Swiss classified compilation re-enacts, at a broader level, the

110. Art 6 of the Bern Convention of 19 September 1979 on the Conservation of European Wildlife and Natural Habitats [ETS N 104] and its Annex II.

111. A proposed new article, art 7a(1)(b), of the Hunting and Protection of Wild Mammals and Birds Act (Loi fédérale sur la chasse et la protection des mammifères et oiseaux sauvages) of 20 June 1986 [LChP; RS 922.0]) will be submitted to referendum on 27 September 2020.

112. Schlesinger and others (n 22) 319-20. This propensity can be traced back to Cicero and his dream to systematize roman civil law ('ius civile in artem redigendum', see De oratore, 1 , 42). See James Gordley, The Jurists: A Critical History (OUP 2014) 112ff. As, for example, the structure of contemporary continental civil codes has been greatly influenced by the taxonomy of the Justinian Institues (Alan Watson, 'Legal Change: Sources of Law and Legal Culture' (1982-1983) 131 University of Pennsylvania Law Review 1121, 1126ff).

113. Recueil systématique du droit fédéral (RS); Systematische Sammlung des Bundesrechts (SR); Raccolta sistematica del diritto federale (RS).

114. Recueil officiel du droit fédéral (RO) 196717.

115. Art 11 Loi fédérale sur les recueils du droit fédéral et la Feuille fédérale of 18 June 2004 [LPubl; RS 170.512].

116. Pierre Tercier and Christian Roten, La recherche et la rédaction juridiques (7th edn, Schulthess 2016) 27.

117. Loi fédérale sur la protection de la nature et du paysage of 1 July 1966 [LPN; RS 451]. 118. Loi fédérale sur la protection de l'environnement of 7 October 1983 [LPE; RS 814.01]. 
summa divisio, and divides the legal world into human persons and their environment on the one side, and natural and historical things on the other. ${ }^{119}$

These observations of the Swiss example accord with what the anthropologist and philosopher Phillipe Descola points out in his seminal book. ${ }^{120}$ According to him, the legal summa divisio is an incarnation of the central modern foundational dualism - the great epistemological divide - which split the world into subject matter and observer, nature and culture, object and subject. ${ }^{121}$ Amidst the ongoing environmental disaster to which humankind is no mere bystander, ${ }^{122}$ this culturally inherited scheme, which organizes our relationships to the surrounding world and to others be they human or not, has proved to be insufficient, if not harmful. ${ }^{123}$ As Bruno Latour has urged, we should 'retie the Gordian knot' in order to enable ourselves to conceptualize the ecological complexities of today's world, which do not fit into modern categories. ${ }^{124}$ Our axiological anthropocentrism, the species bias according to which we do not only think from a human perspective but always act according to human ends, ${ }^{125}$ has become a blind spot in legal thinking. For example, the return of large carnivores in compartmentalized European landscapes shows that promoting a form of conservation based on the comfortable exclusion of wilderness outside of the human environment - which assumes a clear partition between impassive natural things as pure objects and agentive human subjects as sole persons - is no longer a viable solution to assure both social tolerance and species protection. ${ }^{126}$ Rather, it is necessary to try to build dynamic relationships with the animals with which we share common landscapes. ${ }^{127}$

119. Note that this is also the case at the constitutional level, since the 'Confederation' is empowered by human citizens and living 'creatures' (art 120(2)) are to be acted on in a manner respectful of their dignity (see Jessica Eisen, 'Animals in the Constitutional State' (2018) 15 International Journal of Constitutional Law 909, 929).

120. Philippe Descola, Par-delà nature et culture (Bibliothèque des sciences humaines, Gallimard 2005).

121. ibid $118-27,243$.

122. Stephen R Palumbi, 'Humans as the World's Greatest Evolutionary Force' (2001) 293 Science 1786; Jonathan Lovvorn, 'Climate Change Beyond Environmentalism Part I: Intersectional Threat and the Case for Collective Action' (2016) 29 Georgetown International Law Review 29ff.

123. See Philippe Descola, 'De la Nature universelle aux natures singulières: quelles leçons pour l'analyse des cultures?' in Philippe Descola (ed), Les Natures en question (Odile Jacob 2018) 123-5.

124. Bruno Latour, We Have Never Been Modern (Harvard UP 1993) 3-5; François Ost, 'Audelà de l'objet et du sujet, un projet pour le milieu' in François Ost and Serge Gutwirth (eds), Quel avenir pour le droit de l'environnement? (Presses de l'Université Saint-Louis 1996) $10-13$.

125. On the epistemic level the species bias however remains, since our knowledge of the world is pragmatically mediated through a human referential. See Gérald Hess, Éthique de la nature (Presse Universitaire de France 2013) 162-3.

126. Luigi Boitani and the Group of Experts on Conservation of Large Carnivores, Action Plan for the Conservation of the Wolves (Canis lupus) in Europe (Council of Europe 2000) 16, 22. 127. Luigi Boitani and John DC Linnell, 'Bringing Large Mammals Back: Large Carnivores in Europe' in Laetitia Navarro and Henrique M Pereira (eds), Rewilding European Landscapes (1st edn, Springer 2015) 80. 


\subsection{Foreseeable shortcomings of legal animal rights}

Given that rights confer more power on legal subjects than standards of conduct confer on the beneficiaries of those standards, ${ }^{128}$ there has been a general consensus among animal rights advocates that welcoming certain species into the law through legal subjectivism will foster symbolic and sometimes procedural changes within the available framework, and will allow for stronger protection of certain animals in concrete ways. ${ }^{129}$ However, in order to assess not only the theoretical expediency but also the long-term appropriateness of legal subjectivism for animals, it is critical to remember what is ultimately at stake in such proposed law reforms. As Anne Peters points out, in decision-making processes 'human interests are regularly overestimated. This "fundamental bias" in favour of human interests pervades all levels of regulation and decision-making'. ${ }^{130}$ As I concluded in the previous section, overcoming our axiological anthropocentrism is indeed a critical step in 'ret[ying] the Gordian knot'. ${ }^{131}$ What legal animal rights propose, however, is not a substantial amendment of our axiological anthropocentrism by enabling a renewed understanding of our interconnectedness with animals and their niches, ${ }^{132}$ but rather a means of mechanically containing this axiological anthropocentrism through the interposition of nonhuman juridical counter-parts. ${ }^{133}$ As Gunther Teubner argues:

Animal rights and similar constructs create basically defensive institutions. Paradoxically, they incorporate animals into human society in order to create defences against the destructive tendencies of human society against animals. ${ }^{134}$

In a similar vein, feminist scholars have recently drawn attention to the implications of the unspoken conceptual presence in legal animal rights and environmental law of the bounded individual of liberal thought. ${ }^{135}$ One key aspect of this presence in animal law is the notion of right, understood in a highly polarized and oppositional way, ${ }^{136}$ in fact carrying a 'powerful message of prima facie inviolability'. ${ }^{137}$ As Jessica Eisen highlights, the "critical understanding of the sources and functions of legal rights has not permeated the legal scholarship on animal rights. Metaphors of determinate boundaries and separation remain pervasive in this field, and rights are

128. Charlotte E Blattner, Protecting Animals Within and Across Borders: Extraterritorial Jurisdiction and the Challenges of Globalization (OUP 2019) 307.

129. See, among others, Anne Peters, 'Liberté, Égalité, Animalité: Human-Anmal Comparisons in Law' (2016) 5 Transnational Environmental Law 25, 51.

130. Peters (n 87) 28; Regina Binder, 'Animal Welfare Regulation: Shortcomings, Requirements, Perspectives. The Case for Regulating the Human-Animal Relationship' in Peters, Stucki and Boscardin (n 87) 77-9.

131. See section 4.1 .

132. Rodman (n 60) 97.

133. ibid 92.

134. Teubner (n 84) 521.

135. Catharine MacKinnon, 'Of Mice and Men: A Feminist Fragment on Animal Rights' in Sunstein and Nussbaum (n 59) 266ff; Jessica Eisen, 'Beyond Rights and Welfare: Democracy, Dialogue and Animal Welfare Act' (2018) 51 University of Michigan Journal of Law Reform 469, 491ff; Sara L Seck, 'Relational Law and the Reimagining of Tools for Environmental and Climate Justice' (2019) 31 Canadian Journal of Women and the Law 151, 154ff.

136. Perhaps because the critical and progressive Left has taken so long to admit the legitimacy of the animal question. See Will Kymlicka and Sue Donaldson, 'Animal Rights, Multiculturalism, and the Left' (2014) 45 Journal of Social Philosophy 116, $166 f f$.

137. Peters (n 129) 48. 
treated as hard and impervious to social balancing'. ${ }^{138}$ Of course, the use of a boundarylike definition of rights among animal rights activists and scholars ${ }^{139}$ seeks to overcome the structural bias stemming from a legal analysis that systematically overvalues any rights of humans to the detriment of every animal interest. ${ }^{140}$ However, in downplaying the complexity and political significance of judicial decision making ${ }^{141}$ - reducing it to a downstream collision among conflicting prerogatives ${ }^{142}$ or to a matter of upstream knowledge regarding animal sufferings $s^{143}$ - legal animal rights advocates unfortunately fail to move beyond the anthropocentric proclivity of the classical rights-based legal analysis itself. ${ }^{144}$ As Catharine MacKinnon argues, 'How to avoid reducing animal rights to the rights of some people to speak for animals against the rights of other people to speak for animals needs further thought'. ${ }^{145}$ What if the best way to consider animal perspectives in law is not to avoid social balancing, but is rather to reconceive society itself?

As human societies, we are increasingly becoming aware of the interdependence between humans and animals within ecological niches as a very present reality. This is an age in which four of the earth system's limits have been exceeded, ${ }^{146}$ marking the transition from a level of global risk that is economically compensable to a scale of damage that poses an existential threat to the very possibility of life on earth, ${ }^{147}$ that promises unprecedented animal suffering, ${ }^{148}$ and in which we are already seeing ecosystem-scale habitat destruction as a result of human activities. ${ }^{149}$ In this context it is doubtful that extending an individualistic conception of law stemming from Western jurisprudence will be sufficient to reinvent the way Occidental humans and animals live together according to their respective environmental needs. To settle for legal animal rights as the primary tool used to mitigate our

138. Eisen (n 135) 519. See further Francione (n 7) 92, who calls for 'true rights' that impose plain prohibitions devoid of any balancing. The same argument can be made against the proportionality test. See the critique of the relative protection of nonhuman dignity in Swiss law as opposed to the absolute protection of human dignity (Margot Michel, 'Instrumentalisierung und Würde der Kreatur - Eine Annäherung an ein grundlegendes Verhällnis aus juristischer Sicht' in Christoph Ammann and others (n 90) 276-77).

139. See Wise (n 85) 800; and further Tom Regan, Animal Rights, Human Wrongs: An Introduction to Moral Philosophy (Rowman \& Littlefield Publishers 2003) 97-8; Francione (n 7) 103-9; Stucki (n 75) 289; Blattner (n 128) 305-7.

140. Peters (n 129) 49; Stucki (n 75) 297-8; Blattner (n 128) 301.

141. See for example, Robert Post, 'Theorizing Disagreement: Re-Conceiving the Relationship between Law and Politics' (2009) 98 California Law Review 1319, 1322.

142. See for example, Francione (n 7) 92; Stucki (n 75) 259-60.

143. See for example, Thomas G Kelch, 'Towards Universal Principles for Global Animal Advocacy' (2016) 5 Transnational Environmental Law 81, 103.

144. Ted Benton, 'Rights and Justice on a Shared Planet: More Rights or New Relations?' (1998) 2 Theoretical Criminology 149, $157 \mathrm{ff}$.

145. MacKinnon (n 135) 270.

146. Will Stephen and others, 'Planetary Boundaries: Guiding Human Development on a Changing Planet' (2015) 347 Science 736.

147. Dominique Bourg, 'Transcendental Damage Versus Global Risks' in Denise Jodelet, Jorge Vala and Ewa Drozda-Senkowska (eds), Societies Under Threat (Springer 2020) 43-4. 148. See the powerful words of Derrida concerning the zootechnical treatment of animals (Jacques Derrida, L'animal que donc je suis (Galiée 2006) 44-8.

149. Sandra Diaz and others (eds), Summary for Policymakers of the Global Assessment Report on Biodiversity and Ecosystem Services of the Intergovernmental Science-Policy Platform on Biodiversity and Ecosystem Services (IPBES 2019) 22. 
axiological anthropocentrism might be counterproductive in the long run, because it would extend to nonhuman beings a flawed conception of legal relationships as constructions external to self-sufficient individuals, precisely at a time when the question that needs to be asked is: what kind of collective life between humans and animals do we want to institute for future generations $?^{150}$ Indeed, the political project to protect independent individuals from intrusions by the collective, 'is clearest when taken to its extreme: the most perfectly autonomous man is the most perfectly isolated'. ${ }^{151}$ As a result, a growing number of contemporary critical theorists point out that there are no such things as abstract legal subjects, but rather that legal subjects are 'necessarily essentially constituted by social relationships'. ${ }^{152}$ Alongside the pragmatic juridical concerns that a purely individualistic approach to legal animal rights raises, ${ }^{153}$ there is indeed real reason to fear that understanding animal rights as individual will make it difficult to consider appropriately the complex and interdependent relationships that link together humans and animals. ${ }^{154}$ For instance, in different contexts, animals could be conceived as family members, ${ }^{155}$ workers ${ }^{156}$ or sovereigns with whom diplomatic relations should be established. ${ }^{157}$ All of these diverse situations call for context-based legal analysis and for recognition of zoopolitical communities. ${ }^{158}$ As has been noted in the case of humans, ${ }^{159}$ especially women, ${ }^{160}$ abstract legal prerogatives for a few emblematic individuals will not suffice to fill in the enforcement gap that the wide majority of humans and nonhuman animals will still endure in the future. ${ }^{161}$ It is therefore unfortunate that many animal rights scholars neglect, ${ }^{162}$ or even reject, a promising alternative conceptual foundation for positive animal rights and positive human duties; that is to say, social and political communities. ${ }^{163}$ How a

150. See Ost (n 70) 231-2, who, however, does not touch upon human-animal collectiveness. 151. Jennifer Nedelsky, Law's Relations: A Relational Theory of Self, Autonomy, and Law (OUP 2011) 97. Besides, Jessica Eisen points out that it is not coincidental if the paragon of this rational and independent being is a male (Eisen (n 135) 517).

152. ibid 517 and reference cited.

153. It seems indeed more efficient and plausible for jurists and judges to rely on ethological and thus species-based knowledge rather than on some individual assessment for which judges lack time and expertise (Raffael N Fasel, 'The Species Membership Approach', paper delivered in the (Legal) Animal Rights Workshop at the IVR World Congress, 12 July 2019). See also Guillaume Futhazar in this issue.

154. Nedelsky (n 151) $232 \mathrm{ff}$.

155. Will Kymlicka, 'Social Membership: Animal Law Beyond the Property/Personhood Impasse' (2017) 40 Dalhousie Law Journal 123, 136ff.

156. See for example, Alasdair Cochrane, 'Labour Rights for Animals' in Robert Garner and Siobhan O'Sullivan (eds), The Political Turn in Animal Ethics (Rowman \& Littlefield International 2016) 15ff; Kymlicka (n 155) $147 \mathrm{ff}$.

157. Baptiste Morizot, Les diplomates. Cohabiter avec les loups sur une autre carte du vivant (Wild Project 2016) 30.

158. Sue Donaldson and Will Kymlicka, Zoopolis. A Political Theory of Animal Rights (OUP 2011) 67-9.

159. Deckha (n 55) 129.

160. MacKinnon (n 135) 271.

161. At least until the capacity to take proceedings on behalf of animals is not substantially extended beyond its actual scope. For a discussion in the American context, see Cass R Sunstein, 'Can Animals Sue?' in Sunstein and Nussbaum (n 59) $255 \mathrm{ff}$.

162. Donaldson and Kymlicka (n 158) 6-8.

163. ibid 5-10. For a more moderate approach, cf Robert Garner and Siobhan O'Sullivan (eds), The Political Turn in Animal Ethics (Rowman and Littlefield 2016). 
conception of social and political communities can inform animal law remains woefully under-theorized in this field, largely because such frameworks base the content of rights on membership of a group or an institution. ${ }^{164}$

Mapping the moral trajectory of animal law, Charlotte Blattner roughly sketches this evolution in the degree of protection in terms of three 'generations of animal law'. ${ }^{165}$ While the first generation protected the owners' monetary interests and the second generation penalized cruelty to animals in both public and private settings, the third generation of animal welfare laws laid down additional binding rules. Do legal animal rights represent a 'fourth generation' of animal law according to this framework? If one maps the purely moral trajectory of animal law, legal animal rights - using legal subjectivism in order directly and specifically to protect individual animals might plausibly be considered to be morally revolutionary. ${ }^{166}$ But if one maps the legal trajectory of animal law, legal animal rights - because they merely turn legal subjectivism against itself - do not represent a legal revolution, but rather the highest protection that third generation binding rules can offer. ${ }^{167}$ I argue that, in order for a legal theory of animal justice to provoke meaningful social change, ${ }^{168}$ we need to develop a 'fourth-generation' of animal law based on an ecological understanding of human and animal relationships.

\subsection{What would understanding animal rights ecologically change?}

The discussion above has shown that legal animal rights, as promising as they may be for advancing equality of arms among human and certain animal legal subjects, will probably ultimately leave us midstream in the broader task of legally retying the Gordian knot. Such a re-entanglement and retying necessitates a true legal revolution; one which, I argue, could better be initiated by the application of a relational approach to animal law. I name this relational approach an ecological understanding of animal rights in order to insist on the necessary immersion of animal rights in a context of social and phenomenal relations ${ }^{169}$ and within environmental limits. ${ }^{170}$ Contrary to the abstract nature of the traditional liberal understanding, which conceives of rights holders as the cause of legal relationships and understands legal bonds as secondary because they are derived from those individual holders, ${ }^{171}$ an ecological understanding of law would give primacy to the legal relationships which form the basic

164. Kymlicka (n 155) 134ff.

165. Blattner (n 128) 297.

166. Peters (n 87) 24-5.

167. In the same sense, Anne Peters notes that 'the difference between having a right and being the object of welfare standards looks not so much like a difference in kind but more a matter of degree': Peters (n 129) 49; see also Paul Waldau, Animal Studies: An Introduction (OUP 2013) 117.

168. See for example, Eisen (n 135) 494, for whom purely ethical approaches of animal justice such as those of Singer and Regan are inadequate to initiate a legal and political project aspiring to broad social change.

169. Nedelsky (n 151) 12.

170. Ethics Specialist Group of the IUCN World Commission on Environmental Law, Oslo Manifesto (IUCN 2016) paras 3-4; Fritjof Capra and Ugo Mattei, The Ecology of Law: Toward a Legal System in Tune with Nature and Community (1st edn, Berrett-Koehler 2015) 181.

171. See section 2.1 . 
contextual entanglements through which legal subjects become concretely knowable, and in the context of which their rights may appropriately be enforced.

As Jennifer Nedelsky points out, to understand rights in a relational way means bringing 'to the foreground of our attention what has always been the background reality'. ${ }^{172}$ Through rights, law structures pre-existing relationships which are embedded with values such as power, responsibility, trust and obligation. ${ }^{173}$ In so doing, law produces archetypal legal positions ('employer-employee', 'parents-children', 'settlor-trustee-beneficiary', 'debtor-creditor', etc.) whose occupants are entitled with certain rights. ${ }^{174}$ By reversing the central focus of the legal discussion from disentangled individual rights to the relationships which underpin them, an ecological understanding of law moves attention away from a purely negative right of individuals not to be subjected to an action of others, to the kind of relationships that a community actually wants to foster through positive duties. ${ }^{175}$ Through the anthropogenic means of law understood in ecological terms, that is, human-made regulations focusing on legal relationships, it becomes possible to think of non-anthropocentric legal tools that take into account nonhuman ends within specific ecological contexts. Wolf management policies in Europe, for instance, are usually implemented without any sufficient ethological knowledge, and the killing of bold individuals is often carried out in an indiscriminate way that has substantial, destabilizing effects on the packs. ${ }^{176}$ While legal animal rights are ill-suited to encompassing wild animals ${ }^{177}$ and while it has become quite illusionary to think of wild animals as pure 'sovereigns' in those territories where contact with human activities has become inevitable, ${ }^{178}$ an ecological understanding of wolf regulation would focus on legal configurations and protocols that can actually foster coexistence. Ethological evaluation grids assessing wolves' behaviour are promising examples of legal tools available to human authorities who, acknowledging with humility their epistemic speciesism, enable themselves to think non-anthropocentrically in order to react appropriately given the context of wolf-human interaction. ${ }^{179}$

172. Nedelsky (n 151) 237-38.

173. ibid 236. Legal relationships are also conceptually fundamental in an Hohfeldian analysis of rights in terms of jural opposites, though here the relationships are conceived in purely logical terms: WN Hohfeld, 'Some Fundamental Legal Conceptions as Applied in Judicial Reasoning' (1913-1914) 23 Yale Law Journal 16, 30. See also John Finnis speaking about the 'essential correlativity' in any right relationships: John Finnis, 'Natural Law: The Classical Tradition' in Jules L Coleman and Scott Shapiro (eds), The Oxford Handbook of Jurisprudence and Philosophy of Law (OUP 2002) 25.

174. Alexander Somek, The Legal Relation: Legal Theory after Legal Positivism (Cambridge Introductions to Philosophy and Law, CUP 2017) 7.

175. Nedelsky (n 151) 238.

176. Yaffa Epstein, 'Killing Wolves to Save Them? Legal Responses to "Tolerance Hunting" in the European Union and United States' (2017) 26 Review of European Community \& Internation Environmental Law 19, 26.

177. See Regan (n 7) 357; Tom Regan, 'Animal Rights and Environmental Ethics' in Donato Bergandi (ed), The Structural Links Between Ecology, Evolution and Ethics: The Virtuous Epistemic Circle (Boston Studies in the Philosophy of Science, Springer 2013) 123.

178. Cf Donaldson and Kymlicka (n 158) 156ff.

179. See Annex 5 of the Swiss Wolf Plan (Federal Office of the Environment 2016) 24-7 and Policy Support Statements of the Large Carnivore Initiative for Europe: The Management of Bold Wolves (LCIE 2019) 5. 
When extended to animals, legal subjectivism conceptually imports an epistemological and axiological scheme which conceives of individuals as disentangled from the polity (considered as a mere artefact) and separated from ecological niches (considered as pure resources). Both these attitudes are based in the reiteration of the opposition between human persons as pure ends and nonhuman things as pure means. ${ }^{180}$ However, shifting the debate from axiological poles to mutually constitutive relations, an ecological understanding of animal rights helps us to think beyond these essentialized dualisms and to focus on the "necessary tasks of assessing contextual choices and understanding socio-legal transformation'. ${ }^{181}$ Such an ecological understanding would allow us, for example, to think beyond the liberal understanding of autonomy as independence which classically draws an impermeable line between self-sufficient persons and submissive things. ${ }^{182}$ Distancing itself from the definition of ' $\mathrm{t}] \mathrm{h}$ he self that underpins contemporary liberal legalism', ${ }^{183}$ a relational approach to animal law could consider concretely asymmetric relationships without misconceiving them from the outset.

Below I offer a brief illustration of how such an ecological understanding would foster a less anthropocentric view, based on a contextual approach. Among all living beings that could be endowed with legal rights, mosquitos surely are the last candidates considered by serious animal rights advocates. ${ }^{184}$ In an ecological approach of law, though, the mosquito's case becomes less ludicrous. As Thomas Berry says, the difference between the rights of a mosquito, a fish or a human being is not a more-or-less question (where the human standard remains in the background) but a qualitative one. ${ }^{185}$ Accordingly, when we take into account that mosquitos or fish do not relate to their phenomenal world in the same way in which humans relate to theirs, rights as relations become commensurable across and within species. ${ }^{186}$ It is therefore helpful to picture legal issues among human-animal relations as disagreements between humans' and animals' worlds: legal answers are different if we are in wetlands (where we are mere visitors in the mosquitos' world); or in a hospital (a place aiming at sanitary safety for humans); and if mosquitos are just engaged in an innocuous parasitic relationship with humans (gathering human blood without more harm than a sting); or are in a dangerous parasitic relationship with humans (gathering human blood and transmitting diseases). There might be simple ethical solutions for abstract problems, ${ }^{187}$ but there can be no abstract legal answer for

180. See above 4.1 .

181. Eisen (n 135) 528-9.

182. Nedelsky (n 151) $118 \mathrm{ff}$.

183. ibid 160. On the bourgeois genealogy of legal subjectivity, see Schlesinger and others (n 22) 319; Benton (n 144) 162ff; Tuori (n 13) 188ff.

184. Most of the time the mosquito example is set in apagogic arguments, cf Cass R Sunstein, 'What Are Animal Rights' in Sunstein and Nussbaum (n 59) 12.

185. Thomas Berry, 'Rights of the Earth: We Need a New Legal Framwork Which Recognises the Rights of All Living Beings' in Peter Burdon (ed), Exploring Wild Law: The Philosophy of Earth Jurisprudence (Wakefield Press 2011) 229.

186. I refer here to the seminal works of Baltic German biologist Jakob von Uexküll, see Carlo Brentari, Jakob von Uexküll. The Discovery of the Umwelt between Biosemiotics and Theoretical Biology (Springer 2015) 75ff.

187. See for example, Mary Anne Warren, Moral Status: Obligations to Persons and Other Living Things (OUP 2000) 155; Jonathan Pugh, 'Driven to Extinction? The Ethics of Eradicating Mosquitoes with Gene-Drive Technologies' (2016) 42 Journal of Medical Ethics 578, $578 \mathrm{ff}$. 
complex situations. ${ }^{188}$ By gradually attuning our legal attention to situated and entangled relationships between humans and animals ${ }^{189}$ - even those which may seem strange - I argue that an ecological understanding of animal rights would be a substantial step towards the shaping of a new polities in which animals are not reduced to third parties whose rights impose side-constraints on the anthropocentric democratic will, but rather are seen as members of differentiated communities, and whose interests help to shape the anthropogenic but non-anthropocentric society of tomorrow. ${ }^{190}$

\section{CONCLUSION}

Legal animal rights deploy the epistemological and axiological dualist logic of Western legal systems against themselves in order to achieve an ethical and direct protection of animals. In so doing, they appear to offer an expedient but un-revolutionary solution lodged within the long-lasting paradigm of legal subjectivism. Prospectively, however, the ecological need and political urge to forge legal tools that could shape new interspecies ways of living together require that we go beyond the anthropocentric proclivity of legal subjectivism. In order to protect animals as members of concrete social and environmental entanglements, a relational approach to animal rights unveiling the presence of the liberal legal subject and exposing it as an abstract and anthropocentric figment of Western jurisprudence - is therefore needed. The ecological understanding proposed here, developing a non-anthropocentric legal imagination, could be a substantial step towards the institution of new human-animal polities.

188. François Ost and Michel van de Kerchove, De la pyramide au réseau? Pour une théorie dialectique du droit (Presses de l'Université de Saint-Louis 2010) 312-13, no 111-13.

189. For an argument in favour of the development of a biosemiotic method of legal interpretation, see Brian Favre, 'Du droit de l'environnement au droit des environnements. Le contre-exemple de la gestion du loup' in Jean-Patrice Courtois and others (eds) Ecological Perspective/Regard écologique (to be published in 2021).

190. For an argument in favour of a pluralist zoopolis, see Eva Meijer, 'Interspecies Democracies' in Bernice Bovenkerk and Jozef Keulartz (eds), Animal Ethics in the Age of Humans (Springer 2016) 64ff; for concrete case studies, see Sue Donaldson and Will Kymlicka, 'Farmed Animal Sanctuaries: The Heart of the Movement?' (2015) 1 Politics and Animals 50, 63ff; Charlotte E Blattner, Sue Donaldson and Ryan Wilcox, 'Animal Agency in Community: A Political Multispecies Ethnography of VINE Sanctuary’ (2020) 6 Politics and Animals 1, 4ff. 